\title{
Financial instability and banks' balance sheets: A Note
}

\author{
H. Abraham \\ School of Economics, University of Cape Town, \\ Private Bag, Rondebosch 7700, Republic of South Africa \\ Haim.Abraham@uct.ac.za
}

Received June 2011

\begin{abstract}
Following the recent financial crisis, it is sometimes argued that financial institutions should be regulated to a greater extent than before in order to prevent a recurrence of global financial crises. It is argued here that since banks create liquidity ex nihilo in exchange for financial collaterals whose nominal values are subject to market fluctuations, in general, banks' regulation can have only a limited effect on the stability of the financial system. Monetary policy of central banks (i.e., setting short term interest rate) is essential to monitor asset prices and thereby create a stable financial environment.
\end{abstract}

*To whom all correspondence should be addressed.

\section{Introduction}

It is the norm in the banking system that loans make deposits (e.g., Allais, 1987). For any IOU from a borrower maturing at a certain date in the future the bank issues a loan for payment on call. Thus, the bank's balance sheet is a double entry where the liabilities are the bank's loans payable on call and the assets are the borrowers' IOUs payable to the bank sometime in the future. Accordingly, the creation of loans, and thereby liquidity, by banks is not restricted by demand deposits; the creation of liquidity is an internal decision of the bank and is not dictated by the volume of the bank's demand deposits. (The creation of liquidity is an internal decision of the bank because the bank itself decides which IOUs are sufficiently credible for the provision of loans.) Accordingly, it is argued here that based on the fact that (i) loans make demand deposits, and (ii) banks make loans in exchange for collaterals, in the form of IOUs, whose nominal values depend on the state of the economy (e.g., the housing market) - the stability of the banking sector depends on economic stability. Thus, financial crises, and in particular banking crises, are symptoms of economic crises, where economic booms are reversed by economic downturns. This scenario contrasts the current literature (e.g., Diamond \& Dybvig, 1983; Green \& Lin, 2000) where it is claimed that short term deposits make long term loans and consequently mistrust amongst depositors is to blame for bank runs and financial instability. According to that literature, the suspicion and fear of depositors that a significant number of depositors may decide to withdraw their demand deposits from a bank is the cause for the bank to run out of liquidity and consequently to declare bankruptcy.

The paper is structured as follows. The next section outlines the current approach to bank runs which is based on a game theoretic approach of depositors' strategic behaviour. In the same section the shortcoming of this approach to explain financial instability is discussed. In the third section an alternative approach, based on the norm that loans make deposits (Allais, 1987), and that therefore liquidity may be created ex nihilo, is presented. The mortgage market was the trigger for the recent global financial crisis. Accordingly, the fourth section considers the mortgage market as a case in point. Policy implications conclude.

\section{A game theoretic approach to depositors' strategies}

The seminal approach to bank runs and financial instability is Diamond and Dybvig (1983). According to that approach banks keep a greater proportion of loans than demand deposits. Therefore the time at which depositors withdraw their deposits from the bank is a manifestation whether a run is due to take place or not. In particular, if all depositors of a bank are to withdraw their deposits simultaneously, the bank will run out of liquidity and will have to declare bankruptcy. Thus, depositors who initially plan to keep their deposits for a long period of time face a dilemma between keeping their deposits for a long period, as they intended initially, and thereby get a relatively high return while assuming the risk of losing part or all of their deposits in a case of a bank run, or they may decide to cash in their deposits in the short run, contrary to their initial plan, and thereby receive little or no return while securing a receipt of their money deposited. That is, a long term depositor's strategy is to weigh his mistrust of other long term depositors concerning their withdrawal of deposits from the bank against the higher return he gets by keeping the deposit for a longer period of time.

According to the above approach the bank acts as a central 
planner which combines short and long term deposits to maximize total welfare of all depositors in an environment of full certainty, despite the uncertainty that each depositor experiences. The law of large numbers allows the bank to act in an environment of full certainty because the bank has many customers and the bank knows, based on past experience, that a certain proportion of customers are short term depositors and the rest are long term depositors. The bank invests its pooled deposits in long term funds at a certain positive return (suppose, for the sake of a numerical illustration, as is done below, that 1 unit invested yields 2 units at the end of a long term), while if long term funds are redeemed in the short run, no yield is accrued (i.e., 1 unit invested yields the same 1 unit). Given that depositors' aversion to risk is greater than one- that is, their relative risk aversion as measured by their utility function is greater than one- the bank's maximization of total utilities of depositors is superior to a market solution in an environment of uncertainty. The maximization process of the bank, acting as a central planner, yields two potential equilibria; (1) a 'good' equilibrium, where all depositors stick to their initial decisions concerning the time of withdrawing their deposits from the bank. The outcome of the 'good' equilibrium is better than any other possible outcome, as mentioned above, and (2) a 'bad' equilibrium, where the bank will run out of liquidity because long term depositors run on the bank at the time the short term depositors withdraw their deposits. Thus, the validity of the 'good' outcome is predicated upon the requirement that long term depositors will not change their decision by becoming short term depositors due to fear or panic. The lack of sufficient liquidity (should all depositors require their deposits simultaneously), however, which is inherent in the maximization process of the bank acting as a central planner, forces all long term depositors to be suspicious of each other. This leads to the impossibility of the bank's existence. The impossibility of the bank's existence is similar to a 'prisoner's dilemma' (for a discussion of the 'prisoner's dilemma' see e.g., Gibbons (1992:2-4) argument as is now shown.

Think of a situation where all short term depositors have just withdrawn their deposits from the bank as they planned. Observing this, some long term depositors may also decide to withdraw their deposits from the bank for fear that the bank might run out of liquidity should their counterpart long term depositors decide to withdraw earlier than they initially planned. Suppose the bank is now left with liquidity for only one more long term depositor should he wish to withdraw immediately his deposit from the bank, and that there are several long term depositors who might decide to withdraw their deposits from the bank. For the sake of illustration, assume that there are two remaining long term depositors who contemplate withdrawing their deposits from the bank. The matrix below depicts the payoffs of the two remaining depositors should they decide to withdraw their deposits or keep them in the bank (see also Gibbons (1992: 73-75), for a game theoretic scenario different from the 'prisoner's dilemma' approach).
Depositor 1

\begin{tabular}{|c|c|cc|}
\cline { 3 - 3 } & & $\mathrm{R}$ & $\mathrm{W}$ \\
Depositor 2 & $\mathrm{R}$ & 1,0 \\
& $\mathrm{~W}$ & 2,2 & 1,1 \\
\hline
\end{tabular}

The interpretation of the above matrix is as follows. The letter R stands for 'retain' (i.e., do not withdraw funds from the bank) and the letter W stands for 'withdraw'. There are four pairs of payoffs in the matrix (e.g., the pair 1,0 states that if depositor 1 decides to withdraw and depositor 2 decides to retain, then the payoff of depositor 1 will be 1 unit and that of depositor 2 will be 0 units). Accordingly, the pair of payoffs 2,2 indicates that if both depositors decide to retain their funds in the bank, the payoff of each will be 2 units (note that the pair of payoffs 2,2 is admissible for receipt only in the long term); if one depositor decides to retain his funds with the bank and the other to withdraw, then the one who retains will receive nothing and the other will get his investment back. If both depositors decide to withdraw their funds from the bank, each hopes to be first in the queue in order to get his initial investment back, hence the pair 1,1. This, however, is impossible because the bank has only 1 unit of liquidity. Hence, a strategy of withdrawing both depositors' funds is one of bankruptcy.

In an environment of uncertainty and mistrust, the only stable minmax solution is one where both depositors decide to withdraw their funds from the bank. Thus, at the outset this rules out the possibility of the bank's existence. This anomaly has been addressed by Diamond and Dybvig (1983) by claiming that depositors should be insured against such contingency, or the central bank should act as a lender of last resort. Despite the implementation of remedies to deal with bank runs, the pair of payoffs 1,1 is still ruled out on a strategic ground. The failure of the above approach to explain the strategic existence of banks led Green and Lin (2000) to propose an argument as is delineated below.

In order to resolve the above impasse, Green and Lin (2000) propounded the following scenario. Their scenario is similar to Diamond and Dybvig (1983) with the following modification. Suppose that when a rumour of run on the bank becomes publically known, all long term depositors who wish to withdraw their funds from the bank immaturely form a queue such that each one knows his place in the queue. It has been shown that under Green and Lin's (2000) scenario it would be disadvantageous for each long term depositor to withdraw his funds from the bank immaturely. For, if the depositor is last in the queue he would immediately realize that he is better off leaving the queue: if he leaves the queue and waits longer he might receive from the bank 2 units for his investment, if however he leaves at the present time he might at best receive only 1 unit, but also, in a worst case, he might cause a bankruptcy of the bank. The second last long term depositor in the queue, knowing the strategy of the last depositor, will also decide to quit the queue, and so all long term depositors will eventually quit the queue. Hence, under this scenario, 
bankruptcy is impossible, and the only minmax solution in the above matrix of payoffs is 2,2 . The difficulty with this approach is that the formation of a queue, where each depositor knows his place in it, is a restrictive requirement in as far as it prevents any possibility of bankruptcy. In reality, when a panic about a bank failure is set out, all depositors scramble to collect their deposits and no orderly queue is formed. Being aware of that, in reality no depositor will employ a strategy as described above.

It can be concluded that neither the strategic payoffs 1,1 , based on Diamond and Dybvig (1983), nor the strategic payoffs 2,2, based on Green and Lin (2000), are relevant to describe the operation of banks. Therefore the investigation of the occurrence of bank runs and the remedial measures to prevent their occurrence should be sought in a banking structure that complies with the practical operation of banks. In reality, banks do not lend funds as a proportion of deposits they receive from customers, but they rather create loans to the public in exchange for IOUs from the borrowers. This banking practice will now be addressed.

\section{Loans make deposits}

It is a fact that banks lend funds to individuals and corporations in exchange for promises of the borrowers to repay those funds within a certain period of time. That is, banks lend funds, not as proportion to current deposits, but in exchange for borrowers' IOUs as a means of surety to repay the loans. This practice is depicted in the bank's balance sheet below (see e.g. Allais, 1987).

\section{A bank's balance sheet}

Assets

\begin{tabular}{l|l}
\multicolumn{1}{c}{ Assets } & \multicolumn{1}{c}{ Liabilities } \\
\hline $\begin{array}{l}\text { Borrowers' IOUs } \\
\text { (with a certain maturity) } \\
\quad \mathbf{x} \text { amount }\end{array}$ & $\begin{array}{l}\text { Bank's loans to customers } \\
\text { (withdrawal on demand) } \\
\mathbf{x} \text { amount }\end{array}$
\end{tabular}

It is evident from the above balance sheet of the bank that its lending capacity is limited only by the credibility of the sureties that the borrowers present to the bank, while the credibility of those sureties is subject to the bank's viewpoint. To demonstrate the creation of liquidity emanating from the bank's balance sheet, consider the following. Observe that the creation of liquidity is simply a transfer of funds from one bank to another. Thus, label by A the current bank and label by B the bank to which the loanable funds from A are transferred. Accordingly, when a customer withdraws his loanable funds from A and deposits them in B, bank B concurrently assumes liability of the IOUs in Bank A's possession (which are the securities of the borrower from bank A). Hence, the creation of liquidity is a mere interbank trade in IOUs. Thereby, bank A creates ex nihilo an extra quantity of $\mathbf{x}$ nominal units in the economy: $\mathbf{x}$ nominal units have been created without the need for demand deposits from customers.

In light of the above it is apparent that during periods of economic upswing the borrowers' sureties (in the form of IOUs) increase in nominal value, and therefore as a result the banks' loans to their customers are fully secured by the nominal value of the securities which act as sureties. Conversely, during periods of downturn, the borrowers' securities nominal value decline and as a result the banks' loans are left unsecured. Therefore when the cycle of economic downturn is limited, the impact on the stability of the banking system and on the stability of the financial markets is also limited; when, however, the extent of the downturn is significant, a global financial crisis may result, as the world experienced recently. This latter observation is now outlined.

When a decline in asset prices take place the banks' nominal securities fall short of the nominal value of loans. If the decline in asset prices is deemed by the financial market to be prolonged, this can lead to a withdrawal of assets from banks and to a concurrent further drop in the banks' share prices. As a result, the entire financial system may be in a threat of collapse. Note that the trigger of financial collapse has been a decline in asset prices because of an economic downturn. Thus, the stability of the banking system is susceptible to asset price stability.

\section{The market of mortgages}

The housing market is a leading factor of the business cycle. In a competitive environment, people trade on the basis of quid pro quo. The same applies to the market of mortgages. That is, banks offer mortgages in relation to the value of property purchased, while the property acts as collateral for the mortgage taken by the borrower. This practice is confirmed by the above bank's balance sheet. Hence, during a period of housing boom the extent of mortgages is relatively high; and therefore, a downturn in the housing market can create a situation where the equity (i.e., borrowers' IOUs in the form of the property owned by borrower) falls short of the money borrowed, resulting in a bad debt. If in addition the mortgagor is unable to service his loan, the bank has strong incentive to force him to sell his property as soon as possible. The outcome is a further decline in property prices and a decline in the value of the banks' collaterals. A consequent sharp drop in the banks' share price triggers a run on the bank.

Based on the principle that loans make deposits, a financial broker can offer to the public financial derivatives whose underlying asset is the housing property, as has been done prior to the recent financial crisis. Although the nominal value of those financial derivatives is predicated upon the value of the housing market, they can be treated by a financial broker as financial assets on their own right. Therefore the financial broker can offer those derivatives to a bank as collateral against which the bank makes a loan (which is literally a demand deposit) in favour of the financial broker. Note that in this case no physical asset acts as collateral for the financial derivative, while the latter nevertheless acts as collateral for the loan. Moreover, the loan may be used for any purpose and is not limited to buying property. Based on the bank's balance sheet, this accounting practice is admissible. During periods of economic upswing, this practice may lead to no difficulty because the underlying asset of the derivative appreciates in value and thereby creates the market perception that the derivative is valuable. During periods of economic 
downturn, however, the bank may realize that those derivatives are worthless because they have no financial value. This is an example of the extent by which banks can create liquidity ex nihilo, and is a clear presentation how the operation of the financial system may lead to crises.

\section{Policy implications}

The implication of the above analysis is that the stability of the financial system, of which the banking system is a major component, depends on the stability of the real economy. Therefore an orderly functioning of the financial system depends on a suitable monitoring of the business cycle of the economy. That is, the central bank should employ a monetary policy of setting short term interest rates such that during an economic upswing the short term interest rate be raised, and interest rate be lowered during periods of downturn (this sounds obvious, but major central banks did not follow such a policy prior to the recent financial crisis). Such a policy renders business cycles less pronounced, and such a policy ensures that collaterals maintain stability of their monetary value. Conversely, when banks' activities are instead curtailed by a regulator, this would lead to a curtailed economic activity without reducing the potential for a banking and financial instability. This can also exacerbate the risk of failure of the banking and financial system because customers who cannot receive loans from accredited banks will resort to other financial institutions which are less credible.

\section{References}

Allais, M. 1987. 'The credit mechanism and its implications'. In Feiwel, G. (ed.). Arrow and the foundations of the theory of economic policy. New York: New York University Press.

Diamond, D. \& Dybvig, P. 1983. 'Bank runs, deposit insurance, and liquidity', Journal of Political Economy, 91: 401-419.

Gibbons, R. 1992. A primer in game theory. New York: Harvester Wheatsheaf.

Green, E.J. \& Lin, P. 2000. 'Diamond and Dybvig's classic theory of financial intermediation: What's missing?', Federal Reserve Bank of Minneapolis Quarterly Review, 24: 3-13. 